Article

\title{
Inhibitory Effects of Solvent-Partitioned Fractions of Two Nigerian Herbs (Spondias mombin Linn. and Mangifera indica L.) on $\alpha$-Amylase and $\alpha$-Glucosidase
}

\author{
Oluwafemi Adeleke Ojo ${ }^{1,2, *(\mathbb{D})}$, Adeola Agnes Afon ${ }^{1}$, Adebola Busola Ojo ${ }^{3}$ (1), \\ Basiru Olaitan Ajiboye ${ }^{1}$ (D), Babatunji Emmanuel Oyinloye ${ }^{1,4}$ (1) and Abidemi Paul Kappo ${ }^{4}$ (B) \\ 1 Phytomedicine, Biomedical Toxicology and Diabetes Research Laboratories, Department of Biochemistry, \\ Afe Babalola University, Ado-Ekiti 360001, Nigeria; adeolabunmi24@gmail.com (A.A.A.); \\ ajiboyebo@abuad.edu.ng (B.O.A.); babatunjioe@abuad.edu.ng (B.E.O.) \\ 2 Department of Biochemistry, University of Ilorin, Ilorin 240222, Nigeria \\ 3 Department of Medical Biochemistry, Afe Babalola University, Ado-Ekiti 360001, Nigeria; \\ ojoab@abuad.edu.ng \\ 4 Biotechnology and Structural Biology (BSB) Group, Department of Biochemistry and Microbiology, \\ University of Zululand, KwaDlangezwa 3886, South Africa; kappoA@unizulu.ac.za \\ * Correspondence: ojooa@abuad.edu.ng; Tel.: +23-470-3782-4647
}

Received: 4 March 2018; Accepted: 27 April 2018; Published: 26 May 2018

\begin{abstract}
Therapies directed towards controlling hyperglycemia, the hallmark of type-2 diabetes mellitus, go a long way in managing diabetes and its related complications. Reducing glucose level through the inhibition of the relevant carbohydrate hydrolyzing enzymes is one among many routes in the management of diabetes. This study investigates the in vitro enzyme inhibitory and antioxidant properties of solvent-partitioned fractions of Spondias mombin and Mangifera indica leaves; which are used extensively in the treatment of diabetic patients locally. The leaves of S. mombin and M. indica were extracted with methanol and fractionated to obtain $n$-hexane (HF), ethyl acetate (EAF), $n$-butanol (BF), and aqueous (AF) fractions successively. The $\alpha$-amylase and $\alpha$-glucosidase inhibitory activities of fractions of $S$. mombin and $M$. indica leaves were investigated while the antioxidant activity of each fraction was analyzed using iron chelating and ABTS (2,2'-azino-bis(3-ethylbenzothiazoline)-6-sulphonic acid) radical scavenging assay. Our findings indicated that the ethyl acetate fraction of $M$. indica leaves contained a considerably higher $(p<0.05)$ amount of total phenolic, flavonoids, metal ion, and ABTS radical scavenging activity than the ethyl acetate fractions of $S$. mombin. Furthermore, the ethyl acetate fraction of $M$. indica had a considerably higher $(p<0.05)$ inhibitory effect on $\alpha$-glucosidase $\left(\mathrm{IC}_{50}=25.11 \pm 0.01 \mu \mathrm{g} \mathrm{mL}{ }^{-1}\right)$, and $\alpha$-amylase $\left(\mathrm{IC}_{50}=24.04 \pm 0.12 \mu \mathrm{g} \mathrm{mL}{ }^{-1}\right.$ ) activities than the S. mombin fraction. Hence, the inhibitory activities of $S$. mombin and M. indica leaves suggest that they are a potential source of orally active antidiabetic agents and could be employed to formulate new plant-based pharmaceutical and nutraceutical drugs to improve human health.
\end{abstract}

Keywords: Spondias mombin; Mangifera indica; $\alpha$-amylase; $\alpha$-glucosidase; antioxidant activity

\section{Introduction}

Diabetes mellitus (DM) is a major public health problem. The projected prevalence among adults in 2015 was $8.8 \%$, affecting about 415 million adults. The prevalence of diabetes has been predicted to increase to about $10.4 \%$ by 2040 [1]. The recent exponential increase in the prevalence of this chronic disease requires a multiple therapeutic approach in the search of a real solution for diabetes and this includes the development of other alternative or complementary medications. Evidence from 
traditional prescription and scientific investigation reveals optimum therapeutic efficacy of medicinal plants with a good margin of safety. Since medicinal plants form a major part of human food, it is worthwhile to evaluate their inhibitory activity against hyperglycemia [2,3].

Hyperglycemia is considered the major basis for many problems in the diabetic state. Meanwhile, carbohydrates are the main sources of blood glucose and inhibition of relevant enzymes such as $\alpha$-amylase and $\alpha$-glucosidase associated with non-insulin dependent diabetes mellitus is vital in preventing sudden increase in blood glucose. Hence, the inhibition of theses enzymes is the reason why the digestion process of carbohydrates can be retarded and the absorption rate of glucose from the gut decreased to result in an extreme low level of blood glucose. As it was previously mentioned, the ability to maintain low blood glucose level is the hallmark of the treatment of diabetes. Although, this may be accomplished via the use of a standard therapy regimen such as biguanides and insulin secretagogues, the inhibition of $\alpha$-amylase and $\alpha$-glucosidase is another key therapeutic approach to be explored in order to improve glycemic control $[4,5]$. Additional searches for plant-based antidiabetic components would be valuable as revealed by their prominent role in some of the presently accessible orthodox drugs [6].

Spondias mombin L. (Anarcadiaceae) is called "Hog plum", "Iyeye" and "Olosan" (Yoruba) [7]. It is a tree with giant panicles of little white flowers, frequent in farmland and villages, particularly within the forest region in addition to the savannah. In traditional practice, S. mombin is employed in curing duodenal disorders, gonorrhoea, diabetes, psychiatric disorders, and for the removal of the placenta in childbirth. In addition, it is used as an antidiarrheal agent [8], and as an antimicrobial agent as well as for the healing of wounds [9-11]. Iweala and Oludare, also reported the hypoglycemic effects, as well as the biochemical and histological changes of the ethanolic extract of Spondias mombin in alloxan-induced diabetic rats [12]. Pelandjuaic acid, ellagitannins, caffeoyl esters, and anacardic acid are reported to be present in S. mombim [13-15].

Mangifera indica L. (Anacardiaceae) called "Mango", "Mangoro" (Yoruba) is a perennial tree prevalent in rural and semi-urban parts of Nigeria. It is one of the vital tropical plants marketed in the world [16]. It is grown largely in several parts of Africa, particularly in the western parts of Nigeria, where it is valued for its edible fruits. There are numerous conventional uses for the bark, roots, and leaves of $M$. indica throughout the globe. M. indica is used therapeutically to cure several ailments such as asthma, cough, diarrhea, dysentery, leucorrhoea, jaundice, pain, and malaria. Phytochemical studies from different parts of $M$. indica have revealed the presence of phenolic constituents, triterpenes, flavonoids, phytosterol, and polyphenols [17]. M. indica is believed to possess several therapeutic uses including analgesic, anti-inflammatory, antimicrobial as well as immune-stimulant, antioxidant and antilipidemic applications [18,19]. Ethanol extract of $M$. indica peel has been investigated and reported to inhibit $\alpha$-amylase and $\alpha$-glucosidase activities, and to ameliorate diabetes related biochemical parameters in streptozotocin (STZ)-induced diabetic rats [20]. Previous studies have reported extraction of different chemical compounds such as phenolic acid 6-alkenyl-salicylic acid, anarcardic acid, chlorogenic acid, ellagic acid, betulin, coumaroyl, quercetin, and gallic acid from S. mombin, which exhibited different biological activities including antidiabetic, anti-inflammatory and anti-oxidant effects [15,21-24]. On the other hand, studies have reported that bioactive compounds identified from $M$. indica leaves include quercetin and chlorogenic acid which possess anti-oxidant, anti-inflammatory, and antidiabetic activities [25]. The current study aimed to investigate the in vitro enzyme inhibitory activities and antioxidant properties of the S. mombin and $M$. indica leaf solvent-partitioned fractions as potential therapeutic sources, which may be helpful in attaining the normoglycemic state in the diabetic condition. 


\section{Materials and Methods}

\subsection{Chemicals}

All chemical agents and standards were of analytical grade reagents unless otherwise stated. Folin-Ciocalteu's reagent and methanol were purchased from Merck (Darmstadt, Germany). ABTS radical cation (2,2'-azino-bis(3-ethylbenzothiazoline)-6-sulphonic acid), DTNB (5,5-dithio-bis (2-nitrobenzoic) acid), acarbose, $\alpha$-amylase, and $\alpha$-glucosidase were purchased from Sigma-Aldrich (Steinheim, Germany).

\subsection{Plant Material and Extraction Procedure}

Fresh leaves of $S$. mombin and $M$. indica were obtained from Ibadan in Nigeria in September 2017. Fresh leaves of S. mombin and M. indica were identified and documented by Mr. Odewo from Forestry Research Institute of Nigeria (FRIN) with Forest Herbarium Ibadan: FHI 111312 and FHI 111313, respectively as the herbarium number deposited. The fresh leaves were air-dried at normal room temperature and humidity for three weeks and ground to powder using a mechanical blender. To obtain methanol extracts, $100 \mathrm{~g}$ of air-dried leaves were soaked with $800 \mathrm{~mL}$ of methanol and $200 \mathrm{~mL}$

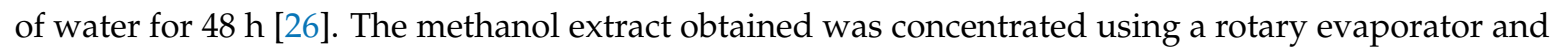
stored until use.

\subsection{Solvent-Partitioned Fractionation of Crude Methanol Extracts}

Methanol leaves extract of S. mombin $(9 \mathrm{~g})$ and M. indica $(15.5 \mathrm{~g})$ was solubilized in $200 \mathrm{~mL}$ of distilled water and sequentially extracted with solvents of increasing polarity (hexane, ethyl acetate, and $n$-butanol). Methanol extract was partitioned between $n$-hexane $(2 \times 200 \mathrm{~mL})$ and water to obtain an $n$-hexane fraction (HF) and an aqueous portion. The aqueous portion obtained was further partitioned by ethyl acetate $(2 \times 200 \mathrm{~mL})$ to obtain an ethyl acetate fraction (EAF) and an aqueous portion. The aqueous portion obtained was further partitioned by $n$-butanol $(2 \times 200 \mathrm{~mL})$ to obtain an n-butanol fraction (BF) and a residual aqueous fraction (AF).

\section{4. $\alpha$-Amylase Inhibitory Activity of Fractions of S. mombin and M. indica Leaves}

Alpha-amylase activity was assessed concurring to the protocol described by [27] with slight modification by [28]. A volume of $300 \mu \mathrm{L}$ of S. mombin and M. indica leaf fractions (HF, EAF, BF, AF) at different concentrations $\left(10-150 \mu \mathrm{g} \mathrm{mL}^{-1}\right)$ was incubated with $500 \mu \mathrm{L}$ of porcine pancreatic amylase $\left(2 \mathrm{U} \mathrm{mL}^{-1}\right)$ in $100 \mathrm{mmol} \mathrm{L}^{-1}$ phosphate buffer $\left(\mathrm{pH} \mathrm{6.8)}\right.$ at $37{ }^{\circ} \mathrm{C}$ for $20 \mathrm{~min}$. Three hundred $\mu \mathrm{L}$ of $1 \%$ starch dissolved in $100 \mathrm{mmol} \mathrm{L}^{-1}$ phosphate buffer $(\mathrm{pH} \mathrm{6.8)}$ was then added to the mixture and incubated at $37^{\circ} \mathrm{C}$ for $1 \mathrm{~h}$. One $\mathrm{mL}$ of dinitrosalicylic acid (DNS) color was then added to the solution and boiled for $10 \mathrm{~min}$. The absorbance of the ensuing mixture was read at $540 \mathrm{~nm}$ and the enzyme inhibitory activity was calculated as percentage of control sample without inhibitors. Acarbose was used as standard.

$$
\alpha-\text { amylase inhibition }(\%)=\frac{\mathrm{A}_{540 \text { control }}-\mathrm{A}_{540 \text { sample }}}{\mathrm{A}_{540 \text { control }}} \times 100
$$

$\mathrm{A}_{540 \text { control }}$ : Absorbance of control at $540 \mathrm{~nm}$; A 540 sample: Absorbance of sample at $540 \mathrm{~nm}$

\section{5. $\alpha$-Glucosidase Inhibitory Activity of Fractions of S. mombin and M. indica Leaves}

Alpha-glucosidase inhibitory activity was determined in line with the protocol by [29], with small alterations by [30]. Briefly, $300 \mu \mathrm{L}$ of $S$. mombin and $M$. indica leaf fractions (HF, EAF, BF, AF), at varying concentrations (10-150 $\left.\mathrm{g} \mathrm{m} \mathrm{m}^{-1}\right)$, was mixed with $500 \mu \mathrm{L}$ of $1.0 \mathrm{U} \mathrm{mL}^{-1} \alpha$-glucosidase solution in $100 \mathrm{mmol} \mathrm{L}^{-1}$ phosphate buffer $\left(\mathrm{pH} \mathrm{6.8)}\right.$ ) at $37^{\circ} \mathrm{C}$ for $15 \mathrm{~min}$. Afterwards, $300 \mu \mathrm{L}$ of p-nitrophenyl- $\alpha$-D-glucopyranoside (pNPG) solution $\left(5 \mathrm{mmol} \mathrm{L}^{-1}\right)$ in $100 \mathrm{mmol} \mathrm{L}^{-1}$ phosphate buffer 
(pH 6.8) was added and then the solution was further mixed at $37^{\circ} \mathrm{C}$ for $20 \mathrm{~min}$. Absorbance of the free $p$-nitrophenol was read at $405 \mathrm{~nm}$ and then the inhibitory activity was expressed as percentage of a the control sample. Acarbose was used as standard.

$$
\alpha-\text { glucosidase inhibition }(\%)=\frac{\mathrm{A}_{405 \text { control }}-\mathrm{A}_{405 \text { sample }}}{\mathrm{A}_{405 \text { control }}} \times 100
$$

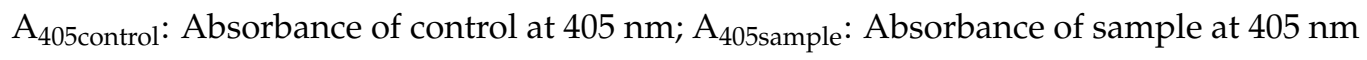

\subsection{Estimation of Total Phenol Content}

S. mombin and M. indica phenol content of the leaf fractions (HF, EAF, BF, AF) was estimated as described by [31]. In short, $200 \mu \mathrm{L}$ fractions (HF, EAF, BF, AF) dispersed in $10 \%$ dimethylsulfoxide (DMSO) $\left(240 \mu \mathrm{g} \mathrm{mL}^{-1}\right)$ was incubated with $1.0 \mathrm{~mL}$ of Folin Ciocalteau (diluted 10 times) and $800 \mu \mathrm{L}$ of $0.7 \mathrm{~mol} \mathrm{~L}^{-1} \mathrm{Na}_{2} \mathrm{CO}_{3}$ for $30 \mathrm{~min}$. Absorbance was read at $765 \mathrm{~nm}$ and all readings were in triplicate with results expressed as $\mathrm{mg}$ gallic acid equivalents (GAE)/100 $\mathrm{g}$ dry fractions.

\subsection{Estimation of Flavonoid Content}

S. mombin and M. indica leaf fractions (HF, EAF, BF, AF) were estimated for flavonoid content using the procedure described by [32]. Briefly, $0.5 \mathrm{~mL}$ of suitably diluted sample was mixed with $0.5 \mathrm{~mL}$ methanol, $50 \mu \mathrm{L} \mathrm{10 \%} \mathrm{AlCl}_{3}, 50 \mu \mathrm{L} 1 \mathrm{M}$ potassium acetate, and $1.4 \mathrm{~mL}$ water, and incubated at room temperature for $30 \mathrm{~min}$. Absorbance of the solution was read at $415 \mathrm{~nm}$. All experiments were in triplicate.

\subsection{Evaluation of Antioxidant Activities of Fractions of S. mombin and M. indica Leaves}

\subsubsection{Iron $\left(\mathrm{Fe}^{2+}\right)$ Chelation}

The metal chelating property of $S$. mombin and M. indica leaf fractions (HF, EAF, BF, AF) was determined by employing an altered procedure of [33]. Freshly prepared $500 \mu \mathrm{mol} \mathrm{L}{ }^{-1} \mathrm{FeSO}_{4}$ $(150 \mu \mathrm{L})$ was mixed to the solution comprising $168 \mu \mathrm{L}$ of $0.1 \mathrm{~mol} \mathrm{~L}^{-1}$ Tris- $\mathrm{HCl}(\mathrm{pH} 7.4), 218 \mu \mathrm{L}$ saline, the aqueous extract (10-150 $\mu \mathrm{L})$, and the fractions. The solution was incubated for $5 \mathrm{~min}$, with addition of $13 \mu \mathrm{L}$ of $0.25 \%(w / v)$ of 1,10-phenanthroline. Ethylenediaminetetraacetic acid (EDTA) was used as standard. Absorbance was read at $510 \mathrm{~nm}$.

\subsubsection{Estimation of 2,2-Azino-bis3-ethylbenthiazoline-6sulphonic acid (ABTS) Radical} Scavenging Ability

S. mombin and M. indica leaf fractions (HF, EAF, BF, AF) were assessed primarily based on the ability to scavenge ABTS using the protocol delineated by [34]. The ABTS was produced by reacting $7 \mathrm{mM}$ ABTS aqueous solution with $\mathrm{K}_{2} \mathrm{~S}_{2} \mathrm{O}_{8}(2.45 \mathrm{mM})$ in the dark for $16 \mathrm{~h}$ and altering the absorbance at $734 \mathrm{~nm}$. Afterward, $200 \mu \mathrm{L}$ of suitable dilution of extracts and fractions was added to $2.0 \mathrm{~mL}$ ABTS solution. Vitamin $C$ was used as standard. Absorbances were read at $734 \mathrm{~nm}$ after $15 \mathrm{~min}$.

\subsection{Data Analysis}

Results were expressed as the mean \pm standard error of mean (SEM) of triplicates [35] from independent samples. Level of significance was set to $p<0.05$. These analyses were presented using one-way analysis of variance (ANOVA) using SPSS version 21.0 (IBM Corporation, NY, USA). 


\section{Results}

\subsection{Inhibitory Effect of Various Fractions of S. mombin and M. indica Leaves against $\alpha$-Amylase}

Figure 1 shows the inhibition percentage of $\alpha$-amylase by various fractions of crude methanol extract of S. mombin, M. indica leaves and standard drug acarbose. The $M$. indica fractions had appreciable in vitro inhibitory activity against $\alpha$-amylase in a fashion, with the ethyl acetate fraction $\left(\mathrm{IC}_{50}=24.04 \pm 0.12 \mu \mathrm{g} \mathrm{mL}{ }^{-1}\right)$ showing a considerably better $(p<0.05) \alpha$-amylase inhibitory activity than S. mombim leaf $\left(\mathrm{IC}_{50}=28.12 \pm 0.48 \mu \mathrm{g} \mathrm{mL}^{-1}\right)$ fractions. However, acarbose had the highest activity against $\alpha$-amylase as shown by the $\mathrm{IC}_{50}\left(22.08 \pm 0.03 \mu \mathrm{g} \mathrm{mL}^{-1}\right)$.

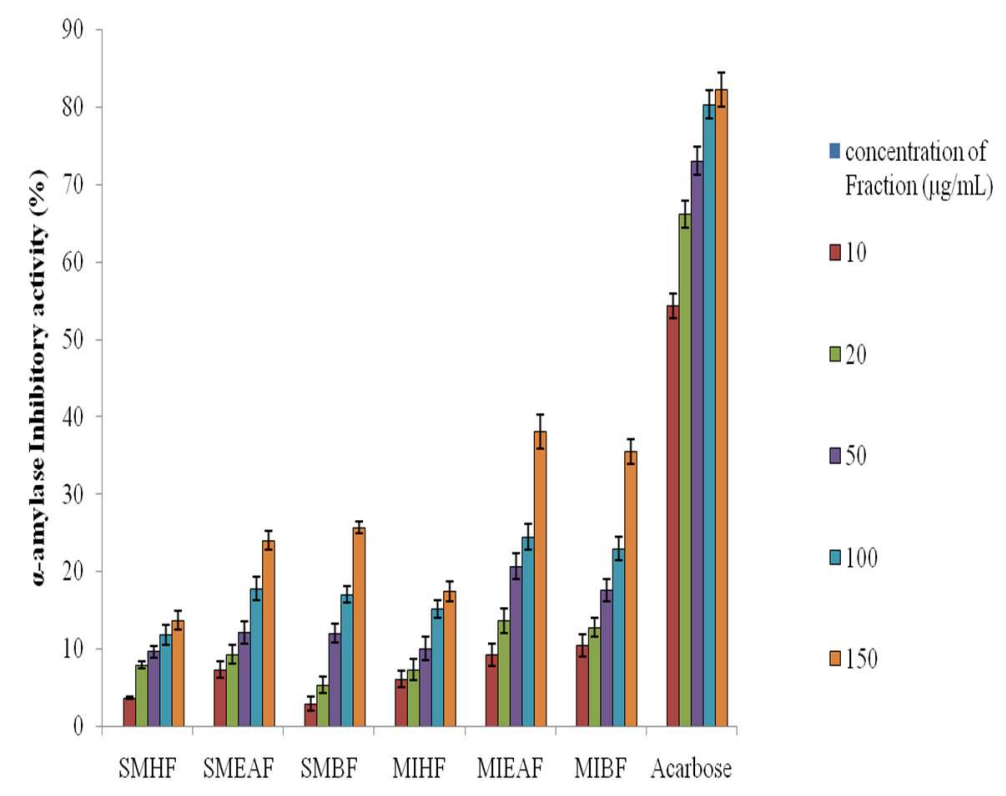

Figure 1. Alpha-amylase inhibitory activity of fractions of S. mombin and M. indica leaves. Legends: SMHF: S. mombin $n$-hexane fraction; SMEAF: S. mombin ethyl acetate fraction; SMBF: S. mombin n-butanol fraction; MIHF: M. indica n-hexane fraction; MIEAF: M. indica ethyl acetate fraction; MIBF: M. indica $n$-butanol fraction.

\subsection{Inhibitory Effect of Various Fractions of S. mombin and M. indica Leaves against $\alpha$-Glucosidase}

Figure 2 shows the percentage inhibition of $\alpha$-glucosidase by various fractions of crude methanol extract of $S$. mombin and $M$. indica leaves. The $M$. indica fractions inhibited $\alpha$-glucosidase activities in vitro. The ethyl acetate fraction displays a better inhibition of $\alpha$-glucosidase activity compared to other fractions. Notably, the inhibitory activity of the ethyl acetate fraction of M. indica $\left(\mathrm{IC}_{50}=25.11 \pm 0.01 \mu \mathrm{g} \mathrm{mL}{ }^{-1}\right)$ was considerably higher $(p<0.05)$ than $S$. mombim $\left(\mathrm{IC}_{50}=12.05 \pm 0.02 \mu \mathrm{g} \mathrm{mL}{ }^{-1}\right)$ fraction as indicated by their $\mathrm{IC}_{50}$ values. However, acarbose had a better inhibitory activity against $\alpha$-glucosidase than $S$. mombin and $M$. indica leaves. 


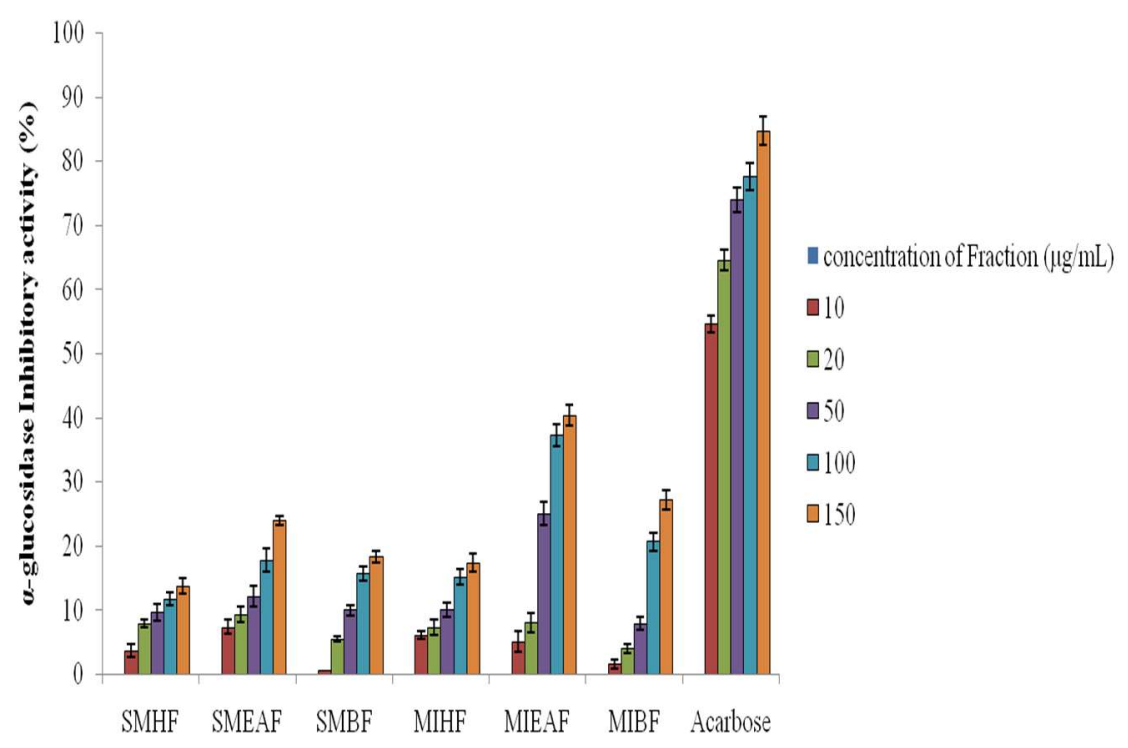

Figure 2. Alpha-glucosidase inhibitory activities of fractions of $S$. mombin and $M$. indica leaves. Legends: SMHF: S. mombin n-hexane fraction; SMEAF: S. mombin ethyl acetate fraction; SMBF: S. mombin $n$-butanol fraction; MIHF: M. indica $n$-hexane fraction; MIEAF: M. indica ethyl acetate fraction; MIBF: M. indica $n$-butanol fraction.

\subsection{Total Phenolics and Total Flavonoids Content of Fractions of S. mombin and M. indica Leaves}

Table 1 reveals the total phenolics, total flavonoids, by various fractions of crude aqueous extract of S. mombin and M. indica leaves. The ethyl acetate fraction of $M$. indica leaves (193.49 $\pm 18.64 \mathrm{mg}$ GAE/100 g) had considerably $(p<0.05)$ higher phenol content than $S$. mombin ethyl acetate fraction $(33.44 \pm 1.57 \mathrm{mg}$ GAE$/ 100 \mathrm{~g})$. Also, the ethyl acetate fraction of $M$. indica (52.35 $\pm 1.23 \mathrm{mg}$ AAE $/ 100 \mathrm{~g}$ ) had appreciably $(p<0.05)$ higher flavonoids (Table 1$)$ than $S$. mombin ethyl acetate fraction (19.86 $\pm 2.89 \mathrm{mg}$ QUE (Quercetin equivalents) $/ 100 \mathrm{~g}$ ).

Table 1. Total phenolic and total flavonoid content of fractions of Spondias mombin and Mangifera indica leaves.

\begin{tabular}{ccccccc}
\hline Parameters/Fractions & SMHF & SMEAF & SMBF & MIHF & MIEAF & MIBF \\
\hline $\begin{array}{c}\text { Total Phenolic } \\
\text { (mg GAE/100 g) }\end{array}$ & $5.23 \pm 0.31$ & $33.44 \pm 1.57$ & $7.73 \pm 1.73$ & $8.10 \pm 2.69$ & $193.49 \pm 18.64$ & $47.73 \pm 2.21$ \\
$\begin{array}{c}\text { Total Flavonoid } \\
\text { (mg QUE/100 g) }\end{array}$ & $3.36 \pm 1.41$ & $19.86 \pm 2.89$ & $5.75 \pm 0.88$ & $4.21 \pm 0.85$ & $52.35 \pm 1.23$ & $17.01 \pm 0.44$ \\
\hline
\end{tabular}

Values are given as mean \pm standard error of mean (SEM) $(n=3)$. QUE: Quercetin equivalents; GAE: Gallic acid equivalents; SMHF: S. mombin $n$-hexane fraction; SMEAF: S. mombin ethyl acetate fraction; SMBF: S. mombin $n$-butanol fraction; MIHF: M. indica $n$-hexane fraction; MIEAF: M. indica ethyl acetate fraction; MIBF: $M$. indica n-butanol fraction.

\subsection{Metal Ion Chelating Ability of Fractions of S. mombin and M. indica Leaves}

The metal ion chelating property of various fractions of S. mombin and M. indica leaves is displayed in Figure 3. This demonstrated that the ethyl acetate fraction of S. mombin $\left(\mathrm{IC}_{50}=21.76 \pm 0.02 \mu \mathrm{g} \mathrm{mL}{ }^{-1}\right)$ had a considerably $(p<0.05)$ higher metal chelating property than M. indica $\left(\mathrm{IC}_{50}=21.82 \pm 0.05 \mu \mathrm{g} \mathrm{mL}{ }^{-1}\right)$, ethyl acetate fractions. However, EDTA had a metal-ion chelating ability better than the fractions. 


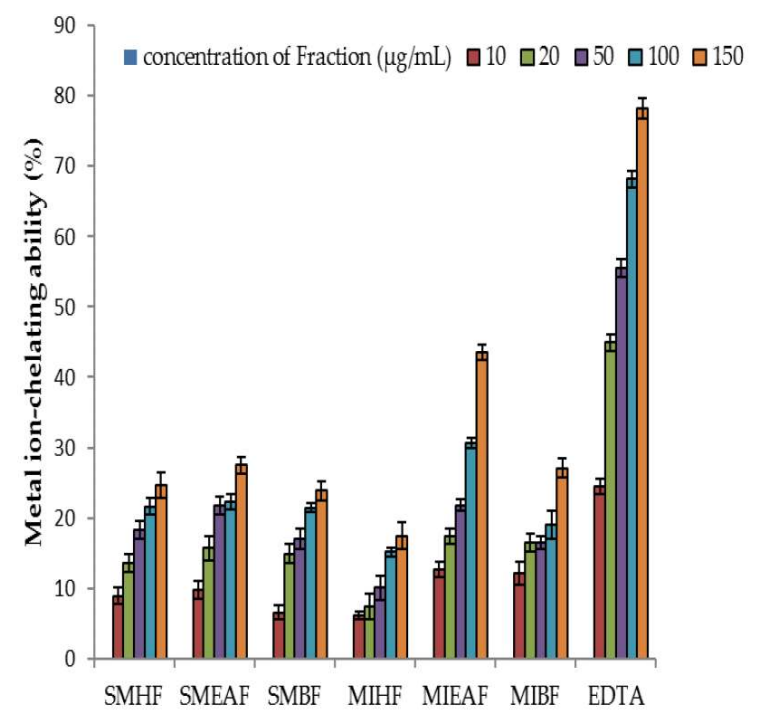

Figure 3. Metal ion chelating property of fractions of S. mombin and M. indica leaves. Legends: SMHF: S. mombin n-hexane fraction; SMEAF: S. mombin ethyl acetate fraction; SMBF: S. mombin n-butanol fraction; MIHF: M. indica $n$-hexane fraction; MIEAF: M. indica ethyl acetate fraction; MIBF: $M$. indica n-butanol fraction; EDTA: ethylenediaminetetraacetic acid.

\subsection{Antioxidant Capacity of Fractions of S. mombin and M. indica Leaves}

The free radical scavenging ability of the various fractions of S. mombin and M. indica leaves was consequently evaluated using the abstemiously steady ABTS radical and is displayed in Figure 4. Results showed that the ethyl acetate fraction of $M$. indica $\left(\mathrm{IC}_{50}=54.88 \pm 0.01 \mu \mathrm{g} \mathrm{mL}{ }^{-1}\right.$ ) quenched ABTS radical (20-100 $\left.\mu \mathrm{g} \mathrm{mL}^{-1}\right)$ better than S. mombin ethyl acetate leaves $\left(\mathrm{IC}_{50}=17.15 \pm 0.02 \mu \mathrm{g} \mathrm{mL} \mathrm{m}^{-1}\right)$, fractions as indicated by their $\mathrm{IC}_{50}$ values. However, vitamin $\mathrm{C}$ scavenged ABTS radical better than the fractions.

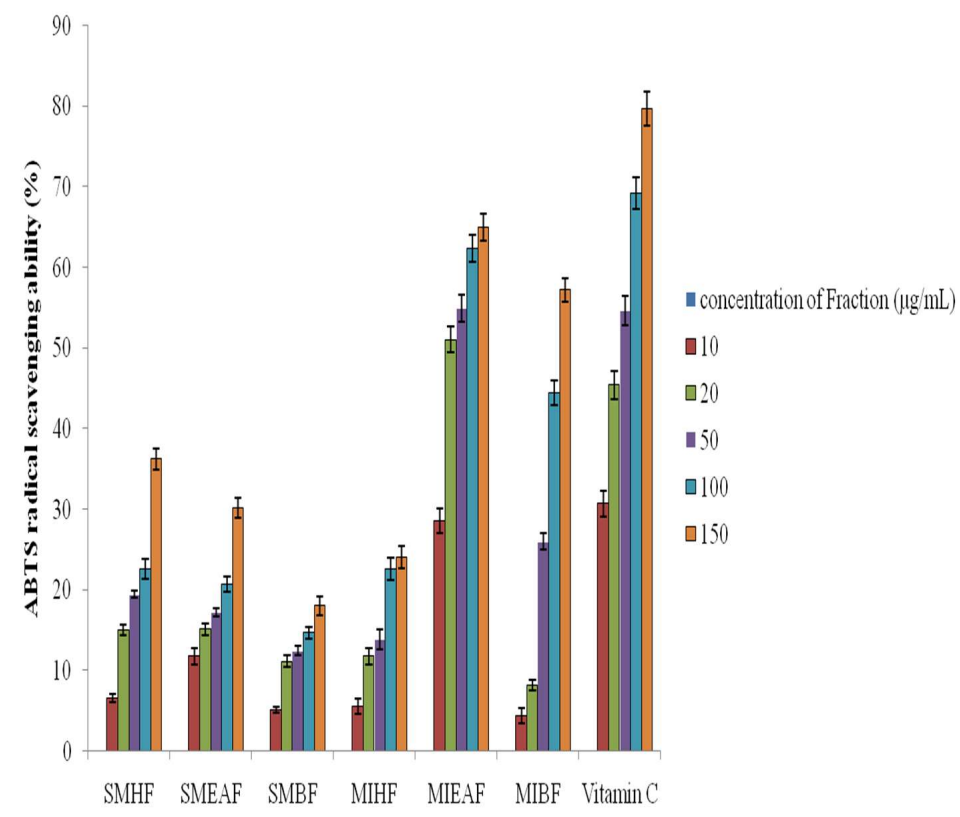

Figure 4. ABTS (2,2'-azino-bis(3-ethylbenzothiazoline)-6-sulphonic acid) radical scavenging ability of fractions of S. mombin and M. indica leaves. Legends: SMHF: S. mombin n-hexane fraction; SMEAF: S. mombin ethyl acetate fraction; SMBF: S. mombin n-butanol fraction; MIHF: $M$. indica $n$-hexane fraction; MIEAF: M. indica ethyl acetate fraction; MIBF: M. indica n-butanol fraction. 


\section{Discussion}

Although several scientific studies have reported the antioxidant and antidiabetic activities of numerous medicinal plants including M. indica and S. mombin [36-41], to the best of our knowledge, this is the first report that directly compares the inhibitory effects of solvent-partitioned fractions of $M$. indica and S. mombin on $\alpha$-amylase and $\alpha$-glucosidase. There are several therapeutic approaches for managing diabetes mellitus; one way to achieve controlled blood glucose levels is to delay glucose absorption via inhibition of relevant carbohydrate hydrolyzing enzymes, such as $\alpha$-amylase and $\alpha$-glucosidase, found in the small intestine. The present study showed that S. mombin and M. indica leaves (HF, EAF, BF, AF) fractions inhibit $\alpha$-amylase and $\alpha$-glucosidase activities. The inhibition of carbohydrate metabolizing enzymes like $\alpha$-amylase and $\alpha$-glucosidase retards the absorption and digestion of starch and later suppresses postprandial symptom. The inhibitory properties of $S$. mombin and M. indica leaf fractions may suggest its usefulness as an oral antidiabetic drug for the management of high blood sugar in patients with these syndromes. Inhibitions of these enzymes interrupt macromolecule digestion and overall extend the breakdown time inflicting a reduction in the degree of glucose ingestion and thus plummeting postprandial blood sugar [30]. Better medical output may be derived from $\alpha$-amylase and $\alpha$-glucosidase inhibitors with mild inhibitory activity against $\alpha$-amylase and strong inhibitory activity against $\alpha$-glucosidase [42]. The inhibition of $\alpha$-glucosidase, together with $\alpha$-amylase by ethyl acetate fractions of M. indica and S. mombin, is considered to be an effective strategy for the control of diabetes by diminishing the absorption of glucose [42,43]. Remarkably, in this study, the ethyl acetate fractions of M. indica and S. mombin validated these properties and hence could be considered for therapeutic approach to retard postprandial hyperglycemia.

Recently, phenolic compounds have attracted great interest for their potential use in the development of new nutraceuticals or pharmaceuticals products due to their remarkable anti-oxidant, anti-inflammatory or antibacterial activities. Although, the protective effects of polyphenols could be in a concentration-dependent manner, recently there has been accumulating evidence in support of the hypothesis that a high-concentration of polyphenols can mechanistically cause adverse effects through pro-oxidative action and negatively affect cell growth, causing toxicity [43]. Several of the present antioxidants show mutagenic and genotoxic responses in cells reflecting their oxidant activity $[44,45]$. Flavonoids are major classes of phenolics and many studies have documented their biological and pharmacological activities $[46,47]$. The phenolic contents of $M$. indica and S. mombin fractions were determined respectively and the ethyl acetate fraction of $M$. indica leaves had higher total phenolic and flavonoid content than S. mombin fractions.

Metal ion chelating ability is important since it reduces the concentration of transition metals [48]. By chelating $\mathrm{Fe}^{2+}$, the generation of hydroxyl radicals in the Fenton reaction may be attenuated and thus prevent damage to biomolecules. Accumulation of iron has been reported to cause an elevation in the generation of free radicals and development of oxidative stress $[49,50]$.

Rice-Evans [51] reported that compounds with phenolic content could play an important role in eliminating radicals. The ABTS. scavenging property of the leaf might be due to the donating ability of the phenolics present in the fractions [52-54]. The antioxidant capacity of the leaves can be linked to their bioactive compounds, mainly antioxidant polyphenols, because of their ability to scavenge free radicals [55]. On this note, we suggest that the phenolic acids present in the fractions of $M$. indica and S. mombin could contribute to the fraction antioxidant activity. Hence, the results might be explained by the higher total phenolic content found in the fraction of M. indica and S. mombin. Similar findings were reported by other researchers, who found a strong correlation between radical scavenging ability and total phenolic contents of different samples [56]. However, the ethyl acetate fraction of M. indica and S. mombin leaf revealed the highest radical reducing ability of all other fractions.

\section{Conclusions}

Conclusively, our results demonstrate that the fractions from S. mombin and M. indica leaves exert an inhibitory activity against $\alpha$-amylase and $\alpha$-glucosidase. This study recommends the use of these plants 
for further in vivo studies to determine their potential in the management of diabetes. In addition, the data obtained compliments the conventional use of S. mombin and M. indica in the management of diabetes.

Author Contributions: O.A.O. designed the study, A.A.A. and A.B.O. carried out the study, A.B.O. wrote the manuscript, O.A.O., B.E.O., and B.O.A. carried out analysis and interpretation of data, B.O.A. assisted with and supervised the manuscript writing, B.E.O. did the first proof reading and A.P.K. The second proof reading. A.P.K. supported the manuscript preparation, made conceptual contributions on data analysis, manuscript drafting, provided administrative support, and critically revised the manuscript. The authors have read and approved the final manuscript.

Funding: Research reported in this article was supported by the South African Medical Research Council (SAMRC) through funding received from the South African National Treasury (Grant Number: PC 57009). Its contents are solely the responsibility of the authors and do not necessarily represent the official views of the South African Medical Research Council.

Conflicts of Interest: The authors declare no conflicts of interest.

\section{References}

1. Cefalu, W.T.; Buse, J.B.; Tuomilehto, J.; Fleming, G.A.; Ferrannini, E.; Gerstein, H.C.; Bennett, P.H.; Ramachandran, A.; Raz, I.; Rosenstock, J.; et al. Update and next steps for Real-World Translation of Interventions for Type 2 Diabetes Prevention: Reflections from a Diabetes Care Editors' Expert Forum. Diabetes Care. 2016, 39, 1186-1201. [CrossRef] [PubMed]

2. Ogunyinka, B.I.; Oyinloye, B.E.; Osunsanmi, F.O.; Kappo, A.P.; Opoku, A.R. Comparative study on proximate, functional, mineral, and antinutrient composition of fermented, defatted, and protein isolate of Parkia biglobosa seed. Food Sci Nutr. 2017, 5, 139-147. [CrossRef] [PubMed]

3. Ojo, O.A.; Ojo, A.B.; Ajiboye, B.O.; Oyinloye, B.E.; Imiere, O.; Adeyonu, O. Ameliorative potentials of Blighia sapida K.D. Koenig bark against pancreatic-cell dysfunction in alloxan-induced diabetic rats. J. Complement. Integr. Med. 2017, 14, 20160145. [CrossRef] [PubMed]

4. Kumar, S.; Narwal, S.; Kumar, V.; Prakash, O. A-glucosidase inhibitors from plants: A natural approach to treat diabetes. Pharmacogn. Rev. 2011, 5, 19-29. [CrossRef] [PubMed]

5. Telagari, M.; Hullatti, K. In-vitro $\alpha$-amylase and $\alpha$-glucosidase inhibitory activity of Adiantum caudatum Linn. and Celosia argentea Linn. extracts and fractions. Indian J. Pharmacol. 2015, 47, 425-429. [PubMed]

6. Shirwaikar, A.; Rajendran, K.; Punitha, I.S. Antidiabetic activity of alcoholic stem extract of Coscinium fenestratum in streptozotocin-nicotinamide induced type 2 diabetic rats. J. Ethnopharmacol. 2005, 97, 369-374. [CrossRef] [PubMed]

7. Ezuruike, U.F.; Prieto, J.M. The use of plants in the traditional management of diabetes in Nigeria: Pharmacological and toxicological considerations. J. Ethnopharmacol. 2014, 155, 857-924. [CrossRef] [PubMed]

8. Iwu, M.M. Handbook of African Medicinal Plants; CRC Press: Boca Raton, FL, USA, 1993; p. 435.

9. Oliver-Bever, B. Medicinal Plants in Nigeria; Being a Course of Four Lectures Delivered in April 1959 in the Pharmacy Department of the Nigerian College of Arts, Science and Technology, Ibadan; Ibadan University press: Ibadan, OY, Nigeria, 1960; p. 760.

10. Kokwaro, J.O. Medicinal Plants of East Africa; East/Africa Literature Bureau: Nairobi, Kenya, 1976; p. 384.

11. Abo, K.A.; Ogunleye, V.O.; Ashidi, J.S. Antimicrobial potential of Spondias mombin, Croton zambesicus and Zygotritonia crocea. Phytother. Res. 1999, 13, 494-497. [CrossRef]

12. Iweala, E.J.; Oludare, F.D. Hypoglycemic effect, biochemical and histological changes of Spondias mombin Linn and Parinari polyandra Benth seeds ethanolic extracts in Alloxan-induced diabetic rats. J. Pharmacol. Toxicol. 2011, 6, 101-110. [CrossRef]

13. Corthout, J.; Pieters, L.A.; Claeys, M.; Vanden Berghe, D.A.; Vlietinck, A.J. Antiviral ellagitannins from Spondias mombin. Phytochemistry 1991, 30, 1129-1130. [CrossRef]

14. Corthout, J.; Pieters, L.; Claeys, M.; Vanden Berghe, D.; Vlietinck, A. Antiviral caffeoyl esters from Spondias mombin. Phytochemistry 1992, 31, 1979-1981. [CrossRef]

15. Corthout, J.; Pieters, L.; Claeys, M.; Geerts, S.; Vanden Berghe, D.; Vlietinck, A. Antibacterial and molluscicidal phenolic acids from Spondias mombin. Planta Med. 1994, 60, 460-463. [CrossRef] [PubMed]

16. Rymbai, H.; Srivastav, M.; Sharma, R.; Patel, C.R.; Singh, A.K. Bioactive compounds in mango and their roles in human health and plant defence-A review. J. Hortic. Sci. Biotechnol. 2013, 88, 369-379. [CrossRef] 
17. Núñez Sellés, A.J.; Vélez Castro, H.T.; Agüero-Agüero, J.; González-González, J.; Naddeo, F.; De Simone, F.; Rastrelli, L. Isolation and Quantitative Analysis of Phenolic Antioxidants Free Sugar and Polyols from Mango (Mangifera indica Linn) Stem Bark Aqueous Decoction Used in Cuba as a Nutritional Supplement. J. Agric. Food Chem. 2002, 50, 762-766. [CrossRef] [PubMed]

18. Islam, M.R.; Mannan, M.A.; Kabir, M.H.B.; Islam, A.; Olival, K.J. Analgesic, anti-inflammatory and antimicrobial effects of ethanol extract of mango leaves. J. Bangladesh Agric. Univ. 2010, 8, 239-244. [CrossRef]

19. Martínez, G.; Delgado, R.; Pérez, G.; Garrido, G.; Núñez Sellés, A.J.; León, O.S. Evaluation of the in vitro antioxidant activity of Mangifera indica: Extract (Vimang). Phytother. Res. 2004, 14, 424-427. [CrossRef]

20. Gondi, M.; Prasada Rao, U.J.S. Ethanol extract of mango (Mangifera indica L.) peel inhibits $\alpha$-amylase and $\alpha$-glucosidase activities, and ameliorates diabetes related biochemical parameters in streptozotocin (STZ)-induced diabetic rats. J. Food Sci. Technol. 2015, 52, 7883-7893. [CrossRef] [PubMed]

21. Coates, N.J.; Gilpin, M.L.; Gwynn, M.N.; Lewis, D.E.; Milner, P.H.; Spear, S.R.; Tyler, J.W. SB-202742 a novel beta-lactamase inhibitor isolated from Spondias mombin. J. Nat. Prod. 1994, 57, 654-657. [CrossRef] [PubMed]

22. Ayoka, A.O.; Owolabi, R.A.; Bamitale, S.K.; Akomolafe, R.O.; Aladesanmi, J.A.; Ukponmwan, E.O. Effect of Fractionated Extracts and Isolated Pure Compounds of Spondias mombin (L. Anacardiaceae) Leaves on Novelty-Induced Rearing and Grooming Behaviours in Mice. Afr. J. Tradit. Complement. Altern. Med. 2013, 10, 244-255. [CrossRef] [PubMed]

23. Cabral, B.; Siqueira, E.M.S.; Bitencourt, M.A.O.; Lima, M.C.J.S.; Lima, A.K.; Ortmann, C.F.; Chaves, V.C.; Fernandes-Pedrosa, M.F.; Rocha, H.A.O.; Scortecci, K.C.; et al. Phytochemical study and anti-inflammatory and antioxidant potential of Spondias mombin leaves. Rev. Bras. Farmacogn. 2016, 26, 304-311. [CrossRef]

24. Elufioye, T.O.; Obuotor, E.M.; Agbedahunsi, J.M.; Adesanya, S.A. Anticholinesterase constituents from the leaves of Spondias mombin L. (Anacardiaceae). Biologics 2017, 11, 107-114. [CrossRef] [PubMed]

25. Alshammaa, D. Preliminary Screening and Phytochemical Profile of Mangifera indica Leave's Extracts, Cultivated in Iraq. Int. J. Curr. Microbiol. Appl. Sci. 2016, 5, 163-173. [CrossRef]

26. Ojo, O.A.; Oloyede, O.I.; Tugbobo, O.S.; Olarewaju, O.I.; Ojo, A.B. Antioxidant and inhibitory effect of scent leaf (Ocimum gratissimum) on $\mathrm{Fe}^{2+}$ and sodium nitroprusside induced lipid peroxidation in rat brain in vitro. Adv. Biol. Res. 2014, 8, 8-17.

27. Shai, L.J.; Masoko, P.; Mokgotho, M.P.; Magano, S.R.; Mogale, A.M.; Boaduo, N.; Eloff, J.N. Yeast alpha glucosidase inhibitory and antioxidant activities of six medicinal plants collected in Phalaborwa, South Africa. S. Afr. J. Bot. 2010, 76, 65-470. [CrossRef]

28. Ojo, O.A.; Ojo, A.B.; Ajiboye, B.O.; Olayide, I.; Fadaka, A.O. Helianthus annuus Leaf Ameliorates Postprandial Hyperglycaemia by inhibiting carbohydrate hydrolyzing enzymes associated with Type-2 diabetes. Iran. J. Toxicol. 2016, 7, 17-22. [CrossRef]

29. Ademiluyi, A.; Oboh, G. Soybean phenolic-rich extracts inhibit key-enzymes linked to type 2 diabetes ( $\alpha$-amylase and $\alpha$-glucosidase) and hypertension (angiotensin I converting enzyme) in vitro. Exp. Toxicol. Pathol. 2013, 65, 305-309. [CrossRef] [PubMed]

30. Ojo, O.A.; Ajiboye, B.O.; Olayide, I.; Fadaka, A.O.; Olasehinde, O.R. Ethyl acetate fraction of bark of Bridelia ferruginea Benth. inhibits carbohydrate hydrolyzing enzymes associated with type 2 diabetes ( $\alpha$-glucosidase and $\alpha$-amylase). Adv. Biores. 2016, 7, 126-133.

31. Mcdonald, S.; Prenzier, P.D.; Autokiwich, M.; Robards, K. Phenolics content and antioxidant activity of olive oil extracts. Food Chem. 2001, 73, 73-84. [CrossRef]

32. Meda, A.; Lamien, C.E.; Romito, M.; Millogo, J.; Nacoulma, O.G. Determination of the total phenolic, flavonoid and praline contents in Burkina Fasan honey, as well as their radical scavenging activity. Food Chem. 2005, 91, 571-577. [CrossRef]

33. Puntel, R.L.; Nogueira, C.W.; Rocha, J.B.T. Krebs cycle intermediates modulate Thiobarbituric Acid Reactive Species (TBARS) production in rat brain in vitro. Neurochem. Res. 2005, 30, 225-235. [CrossRef] [PubMed]

34. Re, R.; Pellegrini, N.; Proteggente, A.; Pannala, A.; Yang, M.; Rice-Evans, C. Antioxidant activity applying an improved ABTS radical cation decolorization assay. Free Radic. Biol. Med. 1999, 26, 1231-1237. [CrossRef]

35. Zar, J.H. Biostatistical Analysis; Prentice-Hall Inc.: Upper Saddle River, NJ, USA, 1984.

36. Ajiboye, B.O.; Ojo, O.A.; Adeyonu, O.; Imiere, O.; Olayide, I.; Fadaka, A.; Oyinloye, B.E. Inhibitory effect of key enzymes relevant to acute type-2-diabetes and antioxidative activity of ethanolic extract of Artocarpus heterophyllus stem bark. J. Acute Dis. 2016, 5, 423-429. [CrossRef] 
37. Fred-Jaiyesimi, A.A.; Wilkins, M.R.; Abo, K.A. Hypoglycaemic and amylase inhibitory activities of leaves of spondias mombin Linn. Afr. J. Med. Med. Sci. 2009, 38, 343-349. [PubMed]

38. Prashanth, D.; Padmaja, R.; Samiulla, D.S. Effects of certain plant extracts on alpha amylase activity. Fitoterapia 2001, 72, 179-181. [CrossRef]

39. Bhuvaneshwari, J.; Khanam, S.; Devi, K. In Vitro enzyme inhibition studies for antidiabetic activity of mature and tender leaves of Mangifera indica var. Totapuri. Res. Rev. J. Microbiol. Biotechnol. 2014, 3, 36-41.

40. Ganogpichayagrai, A.; Palanuvej, C.; Ruangrungsi, N. Antidiabetic and anticancer activities of Mangifera indica cv. Okrong leaves. J. Adv. Pharm. Technol. Res. 2017, 8, 19-24. [PubMed]

41. Moke, E.G.; Ilodigwe, E.E.; Okonta, J.M.; Emudainohwo, J.O.T.; Ajaghaku, D.L.; Erhirhie, O.E.; Chinwuba, P.; Ahante, E. Antidiabetic activity and toxicity evaluation of aqueous extracts of Spondias mombin and Costus afer on Wistar rats. Br. J. Pharm. Res. 2015, 6, 333-342.

42. Ibrahim, M.; Koorbanally, N.; Islam, M.D. Antioxidative activity and inhibition of key enzymes linked to type-2 diabetes ( $\alpha$-glucosidase and $\alpha$-amylase) by Khaya senegalensis. Acta Pharm. 2014, 64, 311-324. [CrossRef] [PubMed]

43. Mohamed, E.L.H.; Siddiqui, M.J.A.; Ang, L.F.; Sadikun, A.; Chan, S.H.; Tan, S.C.; Asmawi, M.Z.; Yam, M.F. Potent $\alpha$-glucosidase and $\alpha$-amylase inhibitory activities of standardized $50 \%$ ethanolic extracts and sinensetin from Orthosiphonstamineus Benth as anti-diabetic mechanism. BMC Complement. Altern. Med. 2012, 12, 176. [CrossRef] [PubMed]

44. Spanou, C.; Stagos, D.; Aligiannis, N.; Kouretas, D. Influence of potent antioxidant leguminosae family plant extracts on growth and antioxidant defense system of Hep2 cancer cell line. J. Med. Food 2010, 13, 149-155. [CrossRef] [PubMed]

45. Ojo, O.A.; Oloyede, O.I. Extracts of Ocimum gratissimum leaves inhibits $\mathrm{Fe}^{2+}$ and sodium nitroprusside induced oxidative stress in rat liver. J. Pharm. Sci. Innov. 2016, 5, 85-89. [CrossRef]

46. Hoensch, H.P.; Oertel, R. The value of flavonoids for the human nutrition: Short review and perspectives. Clin. Nutr. Exp. 2015, 3, 8-14. [CrossRef]

47. Ojo, O.A.; Oloyede, O.I.; Olarewaju, O.I.; Ojo, A.B. In Vitro Antioxidant Activity and Estimation of Total Phenolic Content in Ethyl Acetate Extract of Ocimum gratissimum. Pharmacologyonline 2013, 3, 37-44.

48. Tabert, M.H.; Liu, X.; Doty, R.L.; Serby, M.; Zamora, D.; Pelton, G.H.; Marder, K.; Albers, M.W.; Stern, Y.; Devanand, D.P. A 10-item smell identification scale related to risk for Alzheimer's disease. Ann. Neurol. 2005, 58, 155-160. [CrossRef] [PubMed]

49. Duh, P.D.; Tu, Y.Y.; Yen, G.C. Antioxidant activity of water extract of Harng Jyur (Chrysenthemum morifolium Ramat). Lebnes Wiss Technol. 1999, 32, 269-277. [CrossRef]

50. Oyetayo, F.L.; Ojo, O.A. Dennettia tripetala seeds inhibiting ferrous sulfate-induced oxidative stress in rat tissues in vitro. Oxidants. Antioxi. Med. Sci. 2017, 6, 35-39. [CrossRef]

51. Rice-Evans, C.A.; Miller, N.M.; Paganda, G. Structure-antioxidant activity relationships of flavonoids and phenolic acids. Free Radic. Biol. Med. 1996, 20, 933-956. [CrossRef]

52. Amic, D.; Davidovic-Amic, D.; Beso, D.; Trinajstic, N. Structure radical scavenging activity relationship of flavonoids. Croatia. Chem. Acta. 2003, 76, 55-61.

53. Oboh, G.; Puntel, R.L.; Rocha, J.B.T. Hot pepper (Capsicum annuum, Tepin and Capsicum Chinese, Hernero) prevent $\mathrm{Fe}^{2+}$-induced lipid peroxidation in brain: In Vitro. Food Chem. 2007, 102, 178-185. [CrossRef]

54. Bhandarkar, A.P.; Bhat Rohith, A.; Vinodraj, K.; Shetty Manjunath, S.; Shenoy Ganesh, K. In vitro evaluation of antioxidant activity of Spondias mombim leaf extract: Discovering future avenues for an affordable and efficient antioxidant. Int. Res. J. Pharm. 2015, 6, 164-168. [CrossRef]

55. Mandic, A.L.; Dilas, S.M.; Cetkovic, G.S.; Canadanovic-Brunet, J.M.; Vesna, T.T. Polyphenolic composition and antioxidant activities of grape seed extract. Int. J. Food Prop. 2008, 11, 713-726. [CrossRef]

56. Khan, H.; Jan, S.A.; Javed, M.; Shaheen, R.; Khan, Z.; Ahmad, A.; Safi, S.Z.; Imran, M. Nutritional composition, antioxidant and antimicrobial activities of selected wild edible plants. J. Food Biochem. 2016, 40, 61-70. [CrossRef]

(C) 2018 by the authors. Licensee MDPI, Basel, Switzerland. This article is an open access article distributed under the terms and conditions of the Creative Commons Attribution (CC BY) license (http:/ / creativecommons.org/licenses/by/4.0/). 